\title{
П.С. Шаблей
}

\section{Социальный облик мусульманских служащих в Казахской степи (конец XVIII - середина XIX в.)}

Мусульманские служащие в Казахской степи - это представители татарского, башкирского, казахского, а также других народов, которые были привлечены в органы местного управления, задействованы в сфере образования и конфессионального благоустройства в качестве чиновников низших рангов, письмоводителей, переводчиков, учителей, указных мулл и приходского духовенства. Социальный облик этих лиц (образование, происхождение, доходы, карьерный рост, социальные представления и репрезентации) отражал как общее состояние российской бюрократической системы, так и особенности развития административного, социального и конфессионального устройства в Казахской степи.

В конце XVIII в. Российская империя столкнулась на казахскороссийском пограничье с несколькими стратегическими задачами: было необходимо обсудить и апробировать разнообразные подходы к распространению компетенции российских государственных учреждений и правовых постановлений на территории Казахской степи; требовалось умиротворить казахский народ и не допустить социальных волнений; следовало произвести оценку действительного положения ислама в Степи. Из-за обширного пространства Казахского края и высокой социальной напряженности российские власти понимали, что пограничные управления не в состоянии адекватно оценивать складывающуюся политическую обстановку, осуществлять эффективное взаимодействие с казахской кочевой элитой и каким-то образом воздействовать на внутренние патриархально-родовые отношения. С другой стороны, регулярное использование войска для противодействия различным социальным движениям в Казахской степи вызывало серьезные геополитические опасения [Архив Государственного Совета, 1869, с. 836-837]. Поэтому, отчасти намеренно, в правительственных верхах зарождалась идея о слабом развитии мусульманской религиозности у казахов, с целью использования в Казахской степи 
больших контингентов татарских и башкирских служащих. Они в период подготовки и проведения новых административно-политических реформ по упразднению прежней системы управления у казахов, должны были влиться в сферу функционально значимых видов деятельности и, таким образом, сформировать первоначальный корпус благонадежных кадров и чиновников, которые бы облегчили решение первых бюрократических сложностей в сфере управления и судопроизводства, а также способствовали легитимации новшеств социально-политического благоустройства. Первыми социальными ролями, освоенными мусульманскими служащими, были должности советников при ханах и султанах (фактически тайных осведомителей правительства. - П. Ш.), переводчиков и письмоводителей, и просто мулл для выполнения духовных обязанностей и обучения «татарской грамоте».

Представление правительства о социально-политических перспективах использования мусульманских служащих в Казахской степи опиралось на компетентные мнения и донесения некоторых губернских руководителей. Однако не вся информация о жизни в казахской глубинке совпадала с действительностью. По наблюдениям большинства российских служащих низших рангов и путешественников, побывавших в Казахской степи в конце XVIII в., казахи практически не имели своих мулл и для обрядов пользовались услугами духовных лиц из Средней Азии. Те из них, кто состоял на службе у ханов и султанов, отличались низким уровнем грамотности и профессиональной компетентности, что существенно ослабляло тенденции централизации в системе управления. Религиозные суеверия и индифферентизм, господствовавшие в общественном сознании, были факторами, сдерживавшими развитие общей правовой культуры и социальных институтов, отдавая преимущество местным адатам, имеющим региональные различия в Казахской степи [Прошлое Казахстана, 1999, c. 245-246; Рычков, 1772 , с. 26] ${ }^{1}$. Существенно иное представление о религиозной обстановке в Казахской степи имел глава Уфимского и Симбирского наместничества барон О.А. Игельстром. Религиозная ситуация у казахов была предметом его интереса не столько с точки зрения глубины религиозных чувств, а скорее как возможность сделать ислам более регулируемой системой. О.А. Игельстром в текущей политической ситуации представлял себе выгоды огосударствления мусульманских институтов и практики социальных отношений.

1 | Такие взгляды во многом опирались на социальный опыт прежних государственно-исламских отношений во внутренней России и поэтому воспринимали не столько дескриптивно, сколько оценочно не свойственные другим мусульманам традиции и образ жизни. Вместе с этим некоторые исследователи вполне убедительно доказывают, что представления о религиозном индифферентизме и о «ненастоящем» исламе у казахов также могли быть продуктом татарской интеллектуальной мысли. Татары не только оказали огромное влияние на упрочение традиций мусульманских ритуалов, образования и культуры, но и были главными соперниками. российского просвещения и культуры в Казахской степи в XIX в. Миссионерская деятельность татар в южных регионах Сибири и в Казахстане нашла отражение в мифах и более поздних аульных хрониках. Ссылаюсь с разрешения автора на любезно предложенную мне, но еще не опубликованную работу А. Франка. «Volga Tatars and the «Islamization» of Muslim nomads: a reverse angle on Russia's «civilizion mission». [см. также: Франк, 2001, с. 58-63]. 
В частности, обстановка в Казахской степи в конце XVIII в. (сильно выраженная патриархально-родовая сегментация, отсутствие профессионального слоя государственных служащих, прочная связь синкретической религиозной культуры с повседневной жизнью) благоприятствовала формированию сфер институциональных привязанностей. Такой подход реализовывался через различные процедуры протекторатно-вассальных отношений с казахской знатью: раздача должностей и почетных званий, отправка в Казахскую степь мулл как выражение доверия и особой благосклонности со стороны властей, применение приемлемых для традиционного восприятия норм социальных отношений в улаживании конфликтных ситуаций ${ }^{2}$, использование параллельных и взаимодействующих норм права, языка, национальной и государственной символики, что формировало более интегрированный образ верховной власти и толерантный курс на вовлечение в сферу государственной службы различных национальных и конфессиональных групп [Касымбаев, 2001, с. 56-57; Султангалиева, 2002, с. 51-52]. Поэтому в первое время для правительственных верхов было очень важно связать процесс формирования новых государственных и социальных структур у казахов с процессом исламизации и его антиподом - религиозным индифферентизмом $^{3}$. В реальности же административные руководители сами указывали на отсутствие резких контрастов между исламом и повседневным мировосприятием казахов. В 1789 г. буквально сразу же после образования Оренбургского магометанского духовного собрания (ОМДС) О.А. Игельстром на заседании Совета при Екатерине II докладывал, что «старшины и большая часть народа (казахского. П. Ш.) довольно показали уже опытов своего к вере ревнования». По его мнению, свою привязанность к исламу они доказали просьбами о построении мечетей, наличием мулл как среднеазиатских, так и своих собственных. В качестве аргументов О.А. Игельстром приводил факты приезда к нему в Уфу не менее сорока казахских мулл с различными прошениями, что было обычной практикой для этого периода казахско-русских отношений [Архив Государственного Совета, 1869, c. 840-841]. В конце XVIII века в канцеляриях пограничных властей скопилось множество прошений казахской знати о назначении к ним мулл в качестве письмоводителей, религиозных наставников и учителей грамоты [ГАОО. Ф. 6. Оп. 3. Д. 2373, 1916]. Российские административные институты использовали этот процесс сотрудничества с кочевыми элитами, пытаясь добиться социально-политического расположения, а также внедряя своих людей в аппараты управления Казахской степью, но речь не шла, по всей видимости, о покрови-

2 | Например, в период восстания под руководством батыра Сырыма Датова для переговоров в качестве посредника привлекался муфтий ОМДС Мухаммаджан Хусаинов.

3 | Преувеличение роли России в исламизации кочевников продукт более позднего времени. И эта идея скорее является социальной рефлексией заинтересованных авторов, например, в работах о распространении христианства, миссионерской деятельности, и у чиновников во второй половине XIX в. [Чернавский, 1900, с. 123; Бабков, 1869, с. 44] 
тельстве исламу как таковому4. Уже в 1789 г. контингент командированных мулл составил более 20 человек. Многие из них должны были войти в органы временного управления Казахской степью и в планируемые О.А. Игельстромом расправы (суды) для Младшего жуза [Архив Государственного Совета, 1869, с. 840]. Отбор кандидатов в конце XVIII в. был очень щепетильным. Занималась этим вопросом в основном Оренбургская пограничная комиссия. Личные качества и служебные заслуги были главными критериями для кандидатов, и казанские татары, уже неплохо зарекомендовавшие себя на службе империи как лица верные и благонадежные, были главными претендентами. Из их числа назначались заседатели ОМДС, и они же по указу от 27 ноября 1784 г. командировались в Казахскую степь [Материалы, 1960 , с. 42]. Однако этот выбор не в полной мере себя оправдывал. На первые предложения, разосланные в Казанском наместничестве, откликнулись не многие. 10 сентября 1789 г. казанский и вятский генерал-губернатор Мещерский докладывал Совету при Екатерине II, что «охотчиков не явилось кроме одного служивого татарина Хасана Сейфуллина» [Архив Государственного Совета, 1869, с. 914]. По всей видимости, жители отдаленного казанского наместничества имели смутные представления о характере предстоящей деятельности и местных нравах. Да и сами чиновничьи донесения, рисовавшие приграничных казахов как «диких», «злонамеренных» людей, которые совершают многочисленные набеги на границы, не вселяли оптимизма. Отсутствовал и сильный материальный стимул, поскольку власти первоначально не обещали существенных компенсаций за такую, как могли подумать многие, рискованную службу.

Так как в первые годы желающих было немного, российское правительство расширило социальные и этнические критерии для кандидатов. Именные списки мулл, командированных в 1800-1820 гг. в Казахскую степь, информируют о таком этническом составе: мишарей $(1,2,3,5$ мишарских кантонов) - 19 человек, башкир (5, 7 и 9 башкирских кантонов) - 14 человек, татар из Казанской губернии всего 6 человек [Султангалиева, 2002, с. 232-233]. Более поздние источники, донесения об определении толмачей в волости Аягузского окружного приказа в 1835 г., сообщают нам о следующем: 5 русских, 3 бухарца и 1 татарин [ЦГА РК. Ф. 338. Оп. 1. Д. 883. Л. 52]. Все они представляли различные социальные категории. Среди них были разорившиеся торговцы, крестьяне, стремящиеся приобрести духовное звание и таким

\footnotetext{
4 | В конце XVIII - начале XIX в. процесс отправки мулл в Казахскую степь определялся характером протекторатно-вассальных отношений. Отправляли изначально только к тем, кто заслуживал доверия и расположения [ГАОО. Ф. 6. 0п. 3. Д. 1916. Л. 3]. Многие просьбы об открытии мечетей в степи в начале XIX в. у казахов были отклонены под различными предлогами. Примечательно и то, что мечети в этот период в основном концентрировались в пунктах казахско-русского пограничья, вынуждая казахов чаще их посещать [Памятная..., 1881, с. 88, 97; Султангалиева, 2002, с. 58]. Характерными тенденциями такой политики были и другие моменты: запрещение браков между казахами и башкирами (с 1747 по 1846 гг.), периодические запреты на увольнение башкир в Казахскую степь для отправления религиозных обрядов и обучения грамоте (1853 г.) [Навеки..., 2007, с. 342]. Несмотря на то, что легализация мусульманских институтов и правовых норм, характерных для ведомства ОМДС, в Казахской степи произошла, она была ограничена административным регулированием еще значительнее, чем во внутренней России.
} 
образом избежать воинской службы, или муллы податного состояния, которые в Казахской степи временно освобождались от повинностей 5 . Желание отстраниться от тягот воинской службы также побуждало казаков башкиро-мещеряцкого войска просить свое начальство об увольнении в Казахскую степь для исполнения служебных обязанностей в качестве переводчиков и письмоводителей. Учитывая большую потребность в профессиональных кадрах, административные власти неоднократно удовлетворяли такие прошения [ЦГА РК. Ф. 338. Оп. 1. Д. 184]. В 1837 г. командующий Башкиро-мещеряцким войском сообщал, что «уже значительное число башкир и мещеряков во избежание службы приняли духовные должности» [Султангалиева, 2000, с. 55]. Одним из наиболее легких путей осесть в Казахской степи были распространенные браки татар и башкир с казахами 6 [ГАОО. Ф. 6. Оп. 6. Д. 12474. Л. 195; Отан тарихы (Отечественная история), 2008 (№3), c. 100]. Постепенное увеличение спроса на мусульманских служащих привело к тому, что в начале XIX в. процедура утверждения мулл была упрощена, но не стала неограниченной․ В 1820 г. оренбургский генерал-губернатор П.К. Эссен требовал от Оренбургской пограничной комиссии разобраться с вопросом: деятельность каких мулл «может быть полезной» [Султангалиева, 2000, с. 55]. Вплоть до ликвидации ханской власти в Казахской степи и образования округов с 1822 г. отправка мусульманских служащих проходила в русле отмеченного нами стремления продемонстрировать особую милость пограничных властей к степной аристократии, т.е. как необходимый элемент протекторатно-вассальных отношений. Поэтому лица, не вызывавшие доверия и расположения, не заслуживали подобной благосклонности. Так, Пограничная комиссия в 1811 г. отказала старшине Младшего жуза Кульчакабаеву определить к нему мулл 9-го башкирского кантона по причине неоказания «никаких услуг пограничному начальству, которые бы побуждали иметь к нему уважение» [ГАОО. Ф. 6. Оп. 2. Д. 1916. Л. 3].

Социальный облик первых мусульманских служащих в Казахской степи лишь отчасти соответствовал традиционным типам чиновника российской провинции. Выполняя функции переводчиков, письмоводителей, учителей и мулл при казахской знати, мусульмане, тем не менее, не являлись профессиональными служащими со штатным распорядком и относительно однообразными служебными обязательствами. Кроме своих основных обязанностей мулла, например, мог быть переводчиком, письмоводителем и др. Решение о служебных перемещениях часто принимались на основе частного соглашения.

\footnotetext{
5 | Ш. Ибрагимов в 1874 г. писал, что на свой вопрос, откуда родом мулла, он почти всегда получал ответ: «Был торгующий татарин Казанской губернии» [Отан тарихы (Отечественная история), 2008 (№3), с. 100].

6 | Казахи освобождались от рекрутского набора. С 1808 г. тем из них, кто перешел на оседлый образ жизни, гарантировалась десятилетняя льгота от уплаты налогов и освобождение от всякой службы [Памятная..., 1881, с. 90]

7 | За небольшой период от учреждения ОМДС до 1800 г. в духовном звании был утвержден уже 1921 человек [Материалы по истории Башкирской АССР, 1960, с. 684].
} 
Распространенным способом занятия канцелярских должностей также стало заключение вольнонаемного договора [ЦГА РК. Ф. 338. Оп. 1. Д. 396. Л. 19, 21]. Вместе с этим низкий престиж, скудное вознаграждение, удаленность от центров культурной и политической жизни лишали человека представления о своей службе как о достойной и бескорыстной деятельности. Многие из мусульманских служащих, попадая в Казахскую степь, вынуждены были существовать и за счет вспомогательных неслужебных доходов, например, занимаясь торговлей, разведением скота [Отан тарихы (Отечественная история), 2008 (№3), c. 100]. Выбор переводчиков из татарской или даже среднеазиатской среды был оправдан тем, что они знали обычаи казахского народа, понимали отчасти его язык, поэтому можно было «ручаться и за успех дел и за самое спокойствие народа» [ЦГА РК. Ф. 338. Оп. 1. Д. 883. Л. 53]. Они же стали носителями новой письменной культуры в Казахской степи. Уже в начале XIX в. понятие «письмо» стало неотъемлемым символом нового административного порядка, весомым аргументом, принимаемым на веру, что в немалой степени способствовало укреплению системы протекторатно-вассальных отношений. Казахский этнограф середины XIX в. М.С. Бабаджанов писал, что «письмо и бумага делали очень много в народе шуму и толков. Все, даже сам всемогущественный хан, не могли не повиноваться письму. Это доказывало киргизам силу грамотности». По мнению М.С. Бабаджанова, первые татарские муллы и письмоводители фактически стали для казахов олицетворением учености и грамотности [Бабаджанов, 2007, с. 78-79], что, по всей видимости, должно было обеспечить необходимый уровень доверия к системе делопроизводства, в которое они были вовлечены, и к административным распоряжениям российских властей. Муллы, объясняя смысл указов и даже правила ислама, часто ссылались на письмо в подтверждение истины своих слов [Бабаджанов, 2007, с. 79].

Ограниченная возможность широкого профессионального отбора кандидатов на места канцелярских служащих делала многие чиновничьи должности практически общедоступными даже для малопригодных людей. В связи с этим образ мусульманского служащего накладывался на социальный контекст Казахской степи и на типичное недоверчивое отношение к инородцам на русской службе, что демонстрировало существенные отличия двух уровней восприятия: местного и российского. В 30-е годы XIX в. пограничное начальство объясняло вступление на государственную службу мусульман несколькими причинами. Среди них были и такие: «будучи купцами или приказчиками татары и бухарцы, потеряв кредит или лошадь по неоплате долга, ищут всех средств быть на службе письмоводителями», чтобы «не потерять своих выгод в стяжании и уплате долгов, а служба очень далека от него, он же еще и дальше от нее» [ЦГА РК. Ф. 338. Оп. 1. Д. 883. Л. 52]. Однако и сами мусульмане по некоторым причинам могли быть заинтересованы в службе, как по материальным интересам, так и по перспективам 
карьерного продвижения. Казахская степь в конце XVIII — начале XIX в. была одним из пограничных и малоизученных регионов Российской империи, поэтому активная и результативная деятельность в этом регионе мусульманских служащих могла стать началом или важным элементом развития карьеры. Указ Екатерины II от 27 ноября 1784 г. «... об определении мулл в казахские роды» гарантировал, что «по мере верности и тщания в исполнении на них возлагаемого по службе нашей обнадежить и большим награждением» [Материалы, 1960, с. 42]. За усердие и заслуги в делах по умиротворению Казахского края первый ахун Казахской степи Мухаммеджан Хусаинов уже в 1786 г. получал жалованье из казны в размере 500 рублей [Материалы, 1940, с. 76], а в 1788 г., как известно, он стал первым оренбургским муфтием [Хабутдинов, 2006], судья Уфимской второй нижней расправы коллежский асессор Мендияр Бекчурин был произведен в 1786 г. в надворные советники [Материалы, 1940, с. 76]. Вместе с этим, рассматривая мусульманское образование на территории Российской империи в начале XIX в. как важную часть «приобщения молодого поколения казахской знати к основам российской жизни», административные власти всячески поощряли просветительскую деятельность некоторых мусульман в казахской среде. В 1822 г. оренбургский генерал-губернатор П.К. Эссен предлагал канцлеру Министерства иностранных дел К.В. Нессельроде за проявленное усердие в отношениях с правителями Степного края освободить муллу А.М. Шарипова от государственных податей и повинностей [Косач, 2008, с. 37].

С введением новой системы управления в Казахстане в 18221824 гг. потребность в обеспечении административно-политической системы профессиональными служащими возросла. По положению 1822 г. не только каждый окружной приказ должен был иметь своих переводчиков и толмачей, но и все волостные управления обязаны были обзавестись письмоводителями, знающими русский и татарский языки [Материалы, 1960, с. 94]. Отчеты окружных приказов за 30-е гг. XIX в. свидетельствуют, что они были обеспеченны необходимым штатом чиновников лишь отчасти. В донесении Аягузского округа от 23 апреля 1835 г. указывалось на отсутствие в пяти волостях толмачей и выражалась надежда получить хотя бы по одному переводчику на волость [ЦГА РК. Ф. 338. Оп. 1. Д. 883, Л. 52]. Местные власти, стремясь каким-то образом восполнить нужду в необходимых кадрах, ходатайствовали о введении мулл в штатное положение. По мнению омского областного начальника С.В. Броневского, мулла был необходим при каждом приказе, поскольку, «где власть гражданских мест не может простираться, духовная (власть) может приводить в послушание простыми увещеваниями» [ЦГА РК. Ф. 338. Оп. 1. Д. 396. Л. 9]. Призыв сделать мулл канцелярскими служащими, тем не менее, не повлиял на улучшение их социального положения. Вплоть до 1836 г. они так и не были переведены в штатные должности с казенным содержанием. 
Поэтому, отвечая на ходатайство о закреплении штатных обязательств и преимуществ за муллами в 1835 г., генерал-губернатор Западной Сибири вынужден был признать силу прежних законов, по которым содержание духовенства полностью возлагалось на попечение казахских султанов или на усмотрение окружных приказов [ЦГА РК. Ф. 338. Оп. 1. Д. 184. Л. 2]. В бюджете органов местного управления не было даже предусмотрено отдельных целевых расходов на содержание мулл. В определенных случаях средства на обеспечение мулл предполагалось брать из расходов на благотворительные заведения [Материалы, 1960, c. 147]. Должность муллы при административных учреждениях сама по себе не имела собственного социального престижа. Многие духовные лица, находившиеся при мусульманских приходах, с неохотой соглашались служить в окружных приказах. Так, Акмолинский окружной приказ доносил в 1824 г. в Омское областное правление, что татарин Сагит Усманов отказался занимать должность муллы без жалованья [ЦГА РК. Ф. 338. Оп. 1. Д. 340. Л. 36]. Ряд округов ставили в известность вышестоящее руководство о совершенном отсутствие каких-либо мулл [ЦГА РК. Ф. 338. Оп. 1. Д. 184. Л. 4-5]. Выход власти пытались найти несколькими способами. Анализ формулярных списков мулл бывшего Среднего жуза показывает, что к несению службы допускались кокандские подданные, временно проживавшие в Казахской степи, уволенные казаки башкиро-мещеряцкого войска, лица, не утвержденные ОМДС [ГУОО ИАОО. Ф. 3. Оп. 12. Д. 7683. Л. 27-29]. В Акмолинском приказе, к примеру, в 1837 г. должность толмача и указного муллы одновременно занимал татарин А. Чалышев, а в Каркаралинском к обязанностям муллы был привлечен султанский письмоводитель Салих Сагитов. Становясь толмачом или письмоводителем, мулла, таким образом, приобретал, в отличие от своих обычных доходов, фиксированный оклад в размере 200 рублей в год [ЦГА РК. Ф. 338. Оп. 1. Д. 184. Л. 4-5].

Многие из мулл, привлеченных к служебной деятельности в казахские округа, работали без официальной легализации. Если для духовных лиц, попадавших в Казахскую степь в конце XVIII - начале XIX в., требовалось специальное разрешение Оренбургской пограничной комиссии и кантонных начальников, то с 1834 г. по распоряжению генерал-губернатора В.А. Перовского эта функция перешла к Оренбургскому магометанскому духовному собранию и губернскому правлению [Азаматов, 1999, с. 105]. Большинство документов этого времени показывают, что многие лица, исполнявшие обязанности муллы, не имели специальных разрешений. Разбирая эти случаи, административные власти пытались временно отстранять от исполнения обязанностей служащих, у которых отсутствовал акт ОМДС [ЦГА РК. Ф. 338. Оп. 1. Д. 184. Л. 1, 3, 8]. Однако результативность таких действий была противоречива. Дополнительные бюрократические преграды, необходимость за свой счет добираться до далекой Уфы уменьшали поток желающих легализовать свою деятельность и обрести 
духовный чин. Несмотря на существующие правила, в окружные приказы стали приниматься лица, которые не имели официальных указов и актов губернского правления и ОМДС [ЦГА РК. Ф. 338. Оп. 1. Д. 396. Л. 19, 36-37]. Таким образом, российские институты изначально не создали определенных условий для служебной деятельности в Казахстане. Поэтому дальнейшие расхождения с установленными в нормативных актах правилами лишь усиливали непонимание и новые бюрократические проблемы.

Источником сомнений в эффективности работы административных учреждений могла стать и достаточно широкая доступность искомой должности. Хотя экзамен в ОМДС не был обычной формальностью, но возникшие представления о нем, судя по литературе и данным источников, ставили под сомнение прозрачность и обоснованность указов ОМДС ${ }^{8}$. Во время испытания Духовное собрание проверяло знание шариата и грамотность человека в соответствии с должностным назначением, но в ходе службы многие не подтверждали свою компетентность. Конечно, кроме обычных проблем, характерных для российских провинциальных учреждений, Духовное собрание сталкивалось и с отсутствием у себя специального образовательного центра, не была разработана унифицированная программа экзаменов [Набиев, 2002, c. 40]. Да и в последующем Духовное собрание имело слабое влияние на деятельность подконтрольных ему духовных лиц. Многие инструкции ОМДС не исполнялись в казахских округах, и это являлось характерным примером неупорядоченности механизмов взаимодействия между различными учреждениями и нарушения административной субординации. Так, в 1853 г. ОМДС ставило в известность Пограничное управление, что Баян-Аульский окружной приказ не обращает внимания на правила, установленные оренбургским муфтием Г. Сулеймановым для браков, и продолжает покровительствовать прежним формам семейнобрачных отношений [ЦГИА РБ. Ф. 292. Оп. 3. Д. 5746. Л. 15]. Из этих дел рождались внутренние конфликты, порождавшие череду недоверия к некоторым мусульманским служащим как представителям Духовного собрания, которые представлялись противниками норм адата и интересов казахского общества. В доносах населения на имя военного губернатора или других административных инстанций фигурировали обстоятельства о некомпетентности мулл, их неосведомленности в казахских обычаях. Один из ответчиков, имам Кокчетавского округа Г. Хабибуллин, в свое оправдание заявлял, что «оные (казахи. - П. Ш.) составили приговор по научению самого Чингиза Валиханова (главы округа. - П. Ш.) за то, чтобы сохранить права свои против мер по шариату» [ЦГИА РБ. Ф. 292. Оп. 3. Д. 5481. Л. 1-2]. Образ муллы был помещен в глубокий социальный контекст сложных отношений как между институтами, так

8 | В середине XIX в. российский журнал «Современник» поместил рассказ одного башкира, которому для получения должности в ОМДС приходилось задабривать всех служащих [Нургалиева, 2005, с. 35]. Подобные же оценки давали Ш. Марджани, Ч. Валиханов. А вот Р. Фахретдинов свой экзамен описал иначе: с ним долго беседовали и достаточно глубоко опрашивали [Гарипов, Система...]. 
и между отдельными социальными категориями. Поэтому в середины XIX в. сложились противоречивые представления о мулле. Для одних, например части национальной интеллигенции, он мог быть религиозным догматиком и приверженцем схоластических методов в образовании, для других, испытывающих социальные трудности категорий населения, мулла мог иметь облик алчного и злоупотребляющего своим служебным положением человека. Если мулла демонстрировал свою компетентность в вопросах шариата и образования, а также внушал уважение своим образом жизни, тогда он становился примером для окружающих и сохранял высокий авторитет в обществе. Доверие к религиозным служителям также могло определяться фактом их официального назначения государством, но расположение народа они приобретали не сразу, его нужно было заслужить. Так, в 1824 г. в ответ на жалобу указного муллы М. Абдрахимова о малом почтении к нему казахов, Омское областное правление заявило, что он должен сам «приобрести к себе уважение и любовь добрыми правилами, духовною кротостью и усердием к вере» [ЦГА РК. Ф. 338. Оп. 1. Д. 383. Л. 4]. Российское государство понимало и то, что поддерживать привычный для казахов образ мулл - значит укреплять уверенность народа, чутко реагирующего на малейшие изменения, в мирных намерениях правительства по отношению к широким пластам местной культуры и быта9.

С точки зрения материального достатка положение мусульманских духовных лиц, определяемых к приходам, было менее стабильным, чем чиновников при местном управлении. Они, за исключением высших разрядов (ахунов), не получали из казны никакого содержания и жили на средства прихожан. Ведомость о числе мечетей в округах Области сибирских казахов за 1860 г. свидетельствует, что все приходские духовные лица либо получали добровольные пожертвования от прихожан, либо ничего не получали [ЦГА РК. Ф. 338. Оп. 1. Д. 1557]. Тем не менее материальное состояние прихода было важным условием для открытия новой мечети и назначения при ней духовных лиц. Как правило, губернское начальство просило окружные приказы и ОМДС выяснить, изъявит ли согласие население предоставить средства на содержание предполагаемой мечети и нужного при ней духовенства. Это одна из причин небольшого количество мечетей в Казахской степи и мулл при них, поскольку местному населению было сложно содержать все это за свой счет. Несколько мечетей могли себе позволить только более обеспеченные мусульманские общества. Например, в 1860 г. в Кокчетавском округе была открыта мечеть на условиях принятия ее содержания и нужного при ней духовенства на средства бия Сасынова [ГУОО ИАОО. Ф. 3. Оп. 3. Д. 4320. Л. 25]. В Семипалатинске,

9 | То, что многие новшества в Казахской степи вводились с осторожностью, доказывает верность нашего предположения. Например, в 1850 г. Временный совет по управлению Внутренней (Букеевской) ордой доносил в Оренбургскую пограничную комиссию, что введение метрических книг «может послужить поводом ко многим недоразумениям и ложным толкам» в народе, встречающем «с предубеждением и недоверчивостью всякое нововведение» [История..., 2002, с. 775-776]. 
где проживало одно из самых обеспеченных мусульманских обществ, было во второй половине ХІХ в. семь мечетей [ГУОО ИАОО. Ф. 3. Оп. 3. Д. 4141. Л. 954.].

Муллы, находившиеся в Казахской степи, имели низкий социальный статус и юридически относились к категории государственных крестьян с выплатой необходимых налогов. Закон от 1 декабря 1826 г. подчеркивал, что «духовенство магометанское никаких особенных привилегий по сану своему не имеет, и, состоя в подушном окладе или служебной по кантонам обязанности, отправляет все повинности, и по делам уголовным судится и наказывается наравне с прочими поселянами» [ПСЗ РИ (II, т. 1), 1830, с. 1265]. Однако льготы тоже были. Высшие духовные лица (муфтии и ахуны) были свободны от рекрутских повинностей. Муллы, имам-хатыпы также освобождались от армейской службы, если они получили свои звания до введения мусульманского духовенства в штатное положение (23 января 1836 г.). Кроме того, население приходов добровольно могло взять на себя выплату за своих мулл повинностей [Азаматов, 1999, с. 104]. Например, в Букеевском ханстве муллы были освобождены от уплаты налогов со скота и избавлены от телесных наказаний [Бабаджанов, 2007, с. 85].

У казахов муллы в основном концентрировались в городах и крупных населенных пунктах, так как размеры мусульманских приходов в казахских селениях были значительно меньше, чем в других регионах Российской империи (по норме не менее 200 душ мужского пола, во многих населенных пунктах у казахов не набиралось и 50 человек. - П.Ш.) [Загидуллин, 2007, с. 386]. Кочевой образ жизни препятствовал полноценному функционированию мусульманских институтов в Казахской степи. Распространенным явлением были жалобы в ОМДС о том, что «повсеместно духовные лица ездят за свой счет или спорящиеся, потеряв последнею надежду, сами приезжали к духовному лицу». Вероятно, считает Д.Д. Азаматов, мусульманские судьи возмещали дорожные расходы за счет заявителей [Азаматов, 1999, с. 104]. Такое обременительное существование побуждало приходских мулл искать дополнительные источники дохода. Часто они обращались с просьбами в губернские правления и ОДМС разрешить кочевать вместе с казахами. О таких муллах Б.Н. Юзефович во второй половине XIX в. писал, что они «получают жалованье от хозяина аула, в котором они проживают, большей частью они просто живут на положении нахлебников - едят, пьют за счет хозяина аула и пользуются помещением в какой-нибудь из его кибиток». Главная их обязанность - совершение мусульманского богослужения, обучение детей татарской грамоте и чтение Корана. Некоторые из них могли заниматься ремеслами и мелочной торговлей (хотя с 1826 по 1863 гг. мусульманским духовным лицам была воспрещена торговая деятельность. - П. Ш.) [Артыкбаев, 1993, с. 232]. Многие из мулл были также татарскими учителями, окончившими определенные курсы медресе 
или мактаба ${ }^{10}$. Среди учителей были и простые крестьяне, которые в поисках какого-нибудь заработка часто отправлялись в Казахскую степь. Их социальный облик сам по себе не вызывал у правительства серьезных политических опасений, так как в представлениях государственных чиновников они были бедными, малообразованными людьми, неспособными вести в Степи какую-либо религиозную пропаганду. Больше беспокоила другая проблема - угроза распространения татарской грамотности, что в целом противоречило видам правительства на русификацию образовательной и языковой сферы в Казахстане ${ }^{11}$. Поэтому очевидно, что образ татарского муллы приобрел наибольшие негативные оттенки в период подготовки и проведения новых административно-политических и просветительских преобразований в Казахстане в 60-70-е гг. XIX в. Фактически созданное властью представление о «фанатичном» мулле стало элементом борьбы с застойностью и иррациональностью в прагматичной логике социально-политических изменений.

Актуализация в середине XIX в. татарского вопроса в Казахской степи должна была стать также и мерилом отношения к деятельности определенных мусульманских институтов. Острой критике в 50-60 гг. XIX в. подвергалась деятельность ОМДС. Оренбургский генерал-губернатор Н.А. Крыжановский обвинял Духовное собрание в том, что оно «продолжает производить в мулл людей алчных, не сведущих и не знающих ни русского языка, ни русской грамоты». Таким образом, он пытался не допустить к занятию чиновничьих должностей татар и башкир, обвинял их в фанатизме, а в реальности искал способы ограничения их влияния на народное образование и пути русификации институтов управления [ГАОО. Ф. 6. Оп. 6. Д. 14045/7-8. Л. 53]. Близкую оценку деятельности ОМДС дали известный татарский общественный деятель Ш. Марджани и казахский ученый Ч. Валиханов. Первый видел ОМДС, которое сыграло значительную роль в отстранении его от должности имама, как типичное провинциальное учреждение, погрязшее в мелких проволочках и безрезультативных бюрократических разбирательствах. Заседателей ОМДС он считал невежественными чиновниками, которые превратили этот орган «в орудие мести и занимались травлей смелых и независимых людей» [Юсупов, 2005, с. 56]. Для Ш. Марджани основным принципом в оценке высших мусульманских служащих был высокий уровень религиозных знаний ${ }^{12}$. Должность муфтия, по его представлениям, должен был занимать авторитетный

10 | Например, известные деятели башкирской и татарской культуры М. Гафури, Акмулла во время учебы в троицком медресе «Расулия» неоднократно в поисках заработка отправлялись в Казахскую степь. Там они обучали казахских детей грамоте. В таком качестве они легко могли прослыть за муллу.

11 | Важно заметить, что процент грамотности у татар в середине и в конце XIX в. был выше, чем у многих народов Казахской степи. В межэтническом сравнении, например, грамотных среди русских и татар, живущих среди казахов, в 1897 г. было примерно одинаковое число (34,97 и 34,56\%). Тогда как у казахов всего 4, 71 \% [Отечественная история, 1998 (№5), с. 155].

12 | В его работе «Мустафад ал-ахбар фи ахвал Казан ва Булгар» («Кладезь сведений о делах Казани и Булгара») содержатся описания первых российских муфтиев [Марджани, 2009, с. 10]. 
религиозный деятель, который мог бы стать духовным лидером российских мусульман. Первые муфтии, считал Ш. Марджани, не отвечали таким требованиям. Например, муфтия С. Тевкелева этот выдающийся татарский историк описывал как типичного руководителя поднадзорного учреждения, лишенного личной воли. Ш. Марджани писал: «Хотя он был человеком миролюбивым, но из-за своей невежественности и нерешительности обыкновенно прислушивался к чужому мнению и, будучи человеком беспринципным, не мог совершить ничего достойного» [Юсупов, 2005, с. 55]. Подобная оценка С. Тевкелева хотя и показывает тип провинциального руководителя, но содержит сама по себе много личных обид Ш. Марджани. С другой стороны, Ч. Валиханов, будучи офицером и российским служащим, рассматривал ОМДС как «загнивающий» неэффективный административный институт. По его мнению, получение должности в Духовном собрании зависело от денежного пешпека (подношения, подарка), а само учреждение не могло справляться с большим потоком дел, оставляя многие из них без внимания [Валиханов, 2007, с. 115-116]. Конечно, ОМДС, приравненное к средним судебным местам, фактически стало судом первой инстанции для мусульман. Оно взаимодействовало со всеми основными административными и судебными учреждениями и одновременно следило за деятельностью подведомственных ему духовных лиц. Широкий спектр деятельности Духовного собрания не соответствовал профессиональному и качественному уровню его кадрового обеспечения. В 1836 г. в штате ОМДС состояло всего 17 человек. При этом, за исключением муфтия и 3 членов-заседателей, чины остальных штатных служащих были не выше 12 класса. Если столоначальник получал годовой оклад в размере 600 рублей, то канцелярские служащие низшего разряда только 190 рублей [Ислам..., 2001, с. 117]. На протяжении многих лет ОМДС боролось за улучшение своего штатного благоустройства. Например, в 1843 г. ему удалось добиться прибавки к штату еще одного столоначальника и двух канцелярских служащих, а также увеличить социальный престиж должности секретаря. По расписанию должностей она была включена в 9 класс [ПСЗ РИ (II, т. 18), 1845, с. 617]. Тем не менее эти небольшие меры не решали вопросов эффективной работы ОМДС. Из 751 дела, рассмотренного в муфтияте в 1865-1868 гг., окончательное решение получили только 12, и то только в результате двухлетнего разбирательства [Азаматов, 1999, с. 140]. Фактически это была проблема не только ОМДС, но и ряда других административных и судебных учреждений Российской империи. Слабая обеспеченность профессиональными кадрами и многообразие нормативных расхождений вели не только к злоупотреблениям, но и к излишней бюрократизации. Многие дела неоднократно пересматривались, что сопровождалось долгой перепиской между различными инстанциями. Сами чиновники не имели полного представления о пределах своей власти и беспрерывно по самым даже мелким вопросам 
обращались к вышестоящим институтам. По всей видимости, изъятие казахов из ведения Духовного собрания, как и в целом попытки его реформирования, имели кроме политических также и глубокие административные, социальные мотивы. Современник Ч. Валиханова казахский этнограф М.С. Бабаджанов, также состоявший на службе империи, по-своему актуализировал значение татарского вопроса в свете реформ 60-х гг. XIX в. Он подчеркивал, что «они (татарские служащие. - П. Ш.) вместе с правилами ислама... приучают ордынцев к кляузам и мошенничеству» [Бабаджанов, 2008, с. 85]. Оренбургский генерал-губернатор Н.А. Крыжановский в 1867 г. со всей очевидностью заявлял министру внутренних дел П.А. Валуеву, что нужно поставить мусульманское духовенство «в более правильные отношения с правительством». Он хотел провести реформу, которая не только бы изменила отношение к службе многих мусульманских чиновников, но и представления о них среди населения. По мнению Н.А. Крыжановского, всех духовных лиц следовало «определять к должности не по выбору, а по назначению правительства» (что было в 1868 г. сделано в Казахстане. - П. Ш.). Он предлагал назначить им казенный оклад и таким образом прекратить их существование за счет населения. Если жалованье сделать значительным, то муллы будут дорожить своим местом, а народ в связи с сокращением материальных издержек станет более равнодушным к своим муллам [Дякин, 1998, с. 813-814]. Тот же Н.А. Крыжановский, объехав Уральскую область в 1869 г., сделал важные наблюдения. По его мнению, желание рядовых казахов иметь собственного муфтия было заманчивой идеей, которая, однако, становилась призрачной при упоминании о типичных чертах бюрократической природы этого учреждения. «Лишь только я разъяснил, - писал Н.А. Крыжановский министру внутренних дел А.Г. Тимашеву, - что при муфтии должно быть целое большое управление, содержание которого будет стоить дорого и что все расходы по содержанию муфтия с его управлением падет на киргиз же, что муфтий, кроме того, будет брать с них же страшные наборы, ибо захочет и жить, и нажиться на их счет; то они немедленно отказались сами от этой идеи» [Каратаев, 2006, с. 225]. Хотя, конечно же, в глазах казахской интеллигенции, лидеров национального и общественного движения в конце XIX начале XX в. ОМДС было символом духовного единения мусульман, показателем их гражданского равноправия. Поэтому на фоне событий общественно-политической жизни мусульман Российской империи казахская сторона заняла активную позицию по распространению компетенции ОМДС.

Устойчивое стремление к русификации делопроизводства и повышению образовательного ценза чиновников в середине XIX в. подспудно очерчивало новые линии недоверия к типичным мусульманским служащим, и не только к муллам и татарским учителям, но и к толмачам. В первую очередь под сомнение стала ставиться благона- 
дежность и исполнительность мусульманских переводчиков. По наблюдениям поручика В.К. фон Герна «сплошь и рядом бывало, что казах заявляет или отвечает одно, а переводчик переводит совсем другое». Точно так же, полагал он, переводчики и толмачи поступали с ответами и приказаниями начальства, не знакомого с казахским языком. Таким образом, местное управление, не имея возможности проверить правильность перевода, становилось часто зависимым в своих действиях от переводчика [Герн, 2007, с. 13]. Многие из таких суждений были достаточно стереотипными. Масштабные планы административно-политических и социальных преобразований в Казахской степи не сопровождались адекватной оценкой ситуации. Поэтому желание форсировать внедрение новых бюрократических подходов в систему управления обострило социально-политические трудноразрешимые противоречия.

Привлечение на государственную службу в Казахскую степь мусульман в конце XVIII - середине XIX в. было связано с желанием правительства формировать различные сферы административного и правового регулирования в регионе, где первоначально сложно было задействовать русскоязычное и коренное население. Однако социальный статус мусульманских служащих и приходских мулл был существенно ниже статуса провинциальных российских чиновников. Органы казахского управления постоянно испытывали недостаток в профессиональных кадрах и поэтому вынуждены были принимать на должности переводчиков, письмоводителей и мулл при приказах вольнонаемных и малообразованных лиц. Служба для многих из них не была главным родом деятельности, хотя некоторые из них сделали достаточно значительную карьеру. Бюрократические проволочки, мелкие тяжбы между инстанциями порождали у местного населения недоверчивое отношение к институтам управления и его чиновникам. В середине XIX в. реформы центрального и местного управления в Российской империи должны были изменить образ чиновника. В Казахской степи стал пропагандироваться облик нового государственного служащего (знающего русскую грамоту, законопослушного и компетентного чиновника). Новый образ утверждался на фоне критики сдерживающих факторов (татарское просвещение и культура), которые были главными конкурентами российских преобразований в Казахской степи. 


\section{Сокращения}

ГУО0 ИАОО - Государственное учреждение Омской области «Исторический архив Омской области.

ГАОО - Государственный архив Оренбургской области.

\section{Список источников и литературы}

Азаматов, 1999 - Азаматов Д.Д. Оренбургское магометанское духовное собрание в конце XVIII XIX в. Уфа, 1999.

Артыкбаев, 1993 - Артыкбаев Ж.0. Казахское общество в XIX в.: традиции и инновации. Караганда, 1993.

Архив Государственного Совета. Т.1. Ч. 2. СПб., 1869.

Бабаджанов, 2007 - Бабаджанов М.С. Заметки киргиза о киргизах // М.С. Бабаджанов. Этнография казахов Букеевской Орды. Серия: Библиотека казахской этнографии. Т. 19. Астана, 2007.

Бабков, 1912 - Бабков И.0. Воспоминания о моей службе в Западной Сибири (1859-1875). СПб., 1912.

Валиханов, 2007 - Валиханов Ч.Ч. 0 мусульманстве в степи // Ч.Ч. Валиханов. Избранные произведения. Серия: Библиотека казахской этнографии. Т. 1. Астана, 2007.

Гарипов, Система... - Гарипов Н.К. Система религиозной иерархии у российских мусульман начала XX в. Доступно на: http://www.tataroved.ru/institut/islamoved/publ/5/

Герн, 2007 - Герн фон В.К. Характер и нравы казахов. Серия: Библиотека казахской этнографии. Т. 18. Астана, 2007.

Дякин, 1998 - Дякин В.С. Национальный вопрос во внутренней политике царизма (XIX - начало ХХ в.). СПб., 1998.

Загидуллин, 2007 - Загидуллин И.К. Исламские институты в Российской империи: мечети в европейской части России и Сибири. Казань, 2007.

Ислам..., 2001 - Ислам в Российской империи: законодательные акты, описания, статистика / Сост. и авт. вступ. статьи Арапов Д.Ю. М., 2001.

Коротаев, 2006 - Коротаев Б. Обзор материалов из истории колонизации казахского края в связи с восстанием казахов Оренбургского края в 1869 г. и в начале 1870-х гг. Алматы, 2006.

Касымбаев, 2001 - Касымбаев Ж.К. Государственные деятели казахских ханств в XVIII - первой четверти XIX вв. Хан Жанторе (1759 - 1809). Т. 3. Алматы, 2001.

Косач, 2008 - Косач Г.Г. Ислам в Оренбургской области. М., 2008.

Марджани, 2009 - Марджани Ш. 0 первых российских муфтиях (фрагмент из сочинения Мустафад ал-ахбар фи ахвал Казан ва Булгар («Кладезь сведений о делах Казани и Булгара») / Пер. со старотатарского и публикация А.Н. Юзеева и И.Ф. Гимадеева, вступ. ст. А.Н. Юзеева. // Pax Islamica (Мир ислама). 2009. № 1.

Материалы, 1960 - Материалы по истории Башкирской АССР. Т.5. М., 1960.

Материалы, 1940 - Материалы по истории Казахской ССР (1785-1828 гг.). Т. 4. М.-Л., 1940.

Материалы, 1960 - Материалы по истории политического строя Казахстана. Т.1. А-А., 1960.

Набиев, 2002 - Набиев Р.А. Ислам и государство: культурно-историческая эволюция мусульманской религии на Европейском Востоке. Казань, 2002.

Навеки..., 2007 - Навеки с Россией: Сб. документов и материалов: В 2 ч. Ч.1. Уфа, 2007. 
Ноак, 1998 - Ноак К. Некоторые особенности социальной структуры поволжских татар в эпоху формирования нации (конец XIX - начало XX в.) // Отечественная история. 1998. № 5.

Нурбаев, 2008 - Нурбаев Ж.Е. Факторы и особенности развития ислама в Северном Казахстане // Отан тарихы (Отечественная история). 2008. № 3.

Нургалиева, 2005 - Нургалиева А.М. Очерки по истории ислама в Казахстане. Алматы, 2005.

Памятная..., 1881 - Памятная книжка Западной Сибири. Омск, 1881.

ПСЗ РИ - Полное собрание законов Российской империи. 2-е собрание. Т.1, 18. СПб., 1830, 1845. Прошлое Казахстана, 1999 - Прошлое Казахстана в источниках и материалах: Сборник / Под ред. С.Д. Асфендиярова, П.А. Кунте. Алматы, 1997.

Рычков, 1772 - Рычков Н. Дневные записки путешествия в Киргиз-Кайсацкую степь в 1771 г. СПб., 1772.

Султангалиева, 2002 - Султангалиева Г.С. Западный Казахстан в системе этнокультурных контактов. Уфа, 2002.

Хабутдинов, 2006 - Хабутдинов А.Ю. Российские муфтии от екатерининских орлов до ядерной эпохи. Нижний Новгород, 2006.

ЦГА РК - Центральный государственный архив Республики Казахстан.

ЦГИА РБ - Центральный государственный исторический архив Республики Башкортостан.

Чернавский, 1900 - Чернавский Н. Оренбургская епархия в прошлом и настоящем. Ч.1. Оренбург, 1900.

Юсупов, 2005 - Юсупов М.Х. Шигабутдин Марджани. Казань, 2005.

Франк, 2001 - Allen J. Frank. Muslim Religion Institutions in Imperial Russia: The Islam World of Novouzensk District and the Kazakh Inner Horde, 1780-1910. Leiden-Boston-Koln, 2001. 